\title{
Penggunaan Buah Mangga Guna Menggantikan Mayonaise Dalam Pembuatan Thousand Island Dressing
}

\author{
Nonot Yuliantoro \\ Program Studi Pengelolaan Perhotelan \\ Fakultas Pariwisata - Universitas Pelita Harapan \\ E-mail :nonot.yuliantoro@uph.edu
}

\begin{abstract}
Eating vegetables and fruits is a good habit in maintaining a good diet for everyone. Awareness of nutritional and calorie food intake according to the body's needs has become a culture in people's lifestyles today. Awareness of a good diet encourages research into the development of thousand island dressing products with the basic ingredients of mango as a substitute for mayonnaise. The development of these dressings was analyzed by organoleptic tests to see hedanik and hedonic quality in terms of taste, color, testure and aroma. The use of mangoes in these dressings is expected to be used as an alternative in consuming vegetable or fruit salads using dressings without the ingredients of dairy products so that they can complement a good diet.
\end{abstract}

Keywords: thousand island dressing, mangoes, organoleptic tests.

\begin{abstract}
Abstrak - Mengonsumsi sayur dan buah adalah kebiasaan baik dalam menjaga pola makan yang baik untuk setiap orang. Kesadaran akan asupan makanan yang bernutrisi dan berkalori sesuai kebutuhan tubuh telah menjadi budaya dalam pola hidup masyarakat dewasa ini. Kesadaran akan pola makan yang baik mendorong dilakukan penelitian pengembangan produk pembuatan thousand island dressing dengan bahan dasar buah mangga sebagai pengganti mayonnaise. Pengembangan thousand island dressing ini dianalisa dengan uji organoleptik guna melihat hedanik dan mutu hedonik dalam hal rasa, warna, testur dan aroma. Penggunaan buah mangga pada dressing ini diharapkan bisa digunakan sebagai alternatif dalam mengonsumsi salad sayur atau buah yang menggunakan dressing tanpa kandungan bahan dairy product sehingga bisa melengkapi pola makan yang baik.
\end{abstract}

Kata Kunci: thousand island dressing, buah mangga, tes organoleptik

\subsection{Latar Belakang}

Pola hidup dengan mengonsumsi makanan berserat adalah kebiasaan baik untuk menjaga keseimbangan metabolisme tubuh. Sayuran dan buah-buahan menjadi pilihan sebagai penyeimbang dalam sebuah menu, karena pada umumnya sayuran dan buah-buahan mengandung banyak vitamin dan serat yang dibutuhkan tubuh dalam proses pencernaan, hal ini dikatakan oleh Almatsier (2009). Industri kuliner, dewasa ini banyak menawarkan ragam pilihan makanan yang menyajikan sayuran dan buah sebagai makanan porsi utama. Menurut Gislen (2008), Salad dressing adalah cairan agak kental yang digunakan untuk memberikan rasa pada sayuran segar atau buah-buahan, fungsi dressing pada salad sama halnya fungsi sauce pada makanan yaitu memperkaya rasa dan aroma. Pada dasarnya dressing dapat dibedakan menjadi oil and Vinegar dressing dan emulsified dressing yaitu mencampur beberapa bahan hingga menyatu menjadi satu dressing (Swanson 2015). Jenis-jenis dressing yang favorit dari kategori oil - viegar dan emulsified dressing antara lain italian dressing, classic vinaigrette, green godess dressing, french dressing, ranch dressing, blue cheese dressing hingga thousand island dressing. Berdasarkan latar belakang tersebut maka dalam penelitian ini dibatasi pada jenis mulsified dressing yaitu dressing dengan bahan dasar mayonaise berkarakteristik creamy dan kental yang kaya kandungan nutrisi dan menggunakan bahan dairy product.

Keterbatasan dalam penelitian ini pada jenis dressing yang di pilih untuk di inovasikan adalah thousand island dressing yang bercirikan warna merah bata, creamy dan bertekstur kental. Tujuan melakukan pengembangan thaousand island dressing adalah untuk menghasilkan produk inovasi dressing yang berkarakteristik kental dengan cita rasa yang menyerupai thousand island dressing tanpa menggunakan mayonaise. Bahan utama pengganti mayonaise dalam pembuatan dressing adalah buah mangga, buah mangga yang dipilih adalah jenis mangga harum manis yang mempunyai karakter creamy pada saat dijadikan dressing dan memiliki kandungan yang kaya akan nutrisi. 
Tabel 1. Kandungan Gizi Buah Mangga

\begin{tabular}{|c|l|c|c|}
\hline No & Nutrisi & Unit & $\begin{array}{c}\text { Value per } \\
100 \mathrm{~g}\end{array}$ \\
\hline 1 & Air & gram & 83.46 \\
\hline 2 & Energy & Kcal & 60 \\
\hline 3 & Protein & $\mathrm{g}$ & 0.82 \\
\hline 4 & Lemak & $\mathrm{g}$ & 0.38 \\
\hline 5 & Karbohidrat & $\mathrm{g}$ & 14.98 \\
\hline 6 & Fiber & $\mathrm{g}$ & 1.6 \\
\hline 7 & Gula & $\mathrm{g}$ & 13.66 \\
\hline 8 & Kalsium & $\mathrm{mg}$ & 11 \\
\hline 9 & Besi & $\mathrm{g}$ & 0.16 \\
\hline 10 & Magnesium & $\mathrm{mg}$ & 10 \\
\hline 11 & Pospor & $\mathrm{mg}$ & 14 \\
\hline 12 & Sodium & $\mathrm{mg}$ & 1 \\
\hline 13 & Zinc & $\mathrm{mg}$ & 0.09 \\
\hline 14 & Vitamin C & $\mathrm{mg}$ & 36.4 \\
\hline 15 & Vitamin B6 & $\mathrm{mg}$ & 0.119 \\
\hline 16 & Vitamin E & $\mathrm{mg}$ & 0.9 \\
\hline
\end{tabular}

Sumber: USDA 2016

Perencanaan dalam penelitian pengembangan thousand island dressing dilakukan dengan menentukan tujuan dari penelitian dan pengembangan produk, yaitu memberikan alternatif pilihan thousand island dressing tanpa kandungan mayonnaise sehingga yang bisa dikonsumsi oleh masyarakat yang tidak bisa mengonsumsi dairy product karena alasan tertentu. Mengingat thousand island dressing adalah salah satu jenis dressing yang banyak digemari dikalangan masyarakat.

Pengembangan produk dilakukan dengan menentukan jenis buah yang mempunyai karakteristik tekstur yang creamy untuk dijadikan bahan pengganti mayonnaise, dari berbagai macam uji coba yang dilakukan maka buah mangga jenis harum manis adalah jenis buah yang tepat sebagai bahan utama dan ditambahakan rempah-rempah yang digunakan untuk membuat thousand island dressing yang diharapakan mempunyai kemiripan rasa, tekstur dan aroma dengan thousand island dressing pada umumnya.

Uji coba terbatas dilakukan untuk mendapatkan formula yang tepat untuk menghasilkan kualitas produk yang akan dicapai, dengan menentukan tingkat kematangan buah mangga yang tepat, dan takaran rempah-rempah yang digunakan untuk menghasilkan dressing yang menyeruapai dengan thousand island dressing pada umumnya.

Penyempurnaan dari uji coba terbatas atas pengembangan thousand island dressing dengan menambahkan buah tomat agar supaya menghasilkan warna, aroma dan rasa dengan tingkat kemiripan yang tinggi dengan dressing thousand island pada umumnya.
Setelah didapatkan hasil produk pengembangan dengan tingkat kemiripan yang tinggi dengan produk yang sebenarnya maka dilakukan penganalisaan data dengan uji sensorik yaitu uji organoleptik untuk dianalisa dengan uji hedonik dan uji mutu hedonik.

Dalam penelitian pengembangan thousand island dressing menggunakan bahan-bahan berupa buah mangga jenis harum manis yang sudah matang ditambah dengan sedikit buah tomat dan rempahrempah untuk menghasilkan tekstur yang kental sehingga bisa berguna sebagai pengganti penggunaan mayonnaise. Alat yang digunakan antara lain alat meja kerja, blender, panci alumunium diameter $25 \mathrm{~cm}$, saringan, balloon whisk, sendok makan, pisau, talenan dengan bahan buah mangga arum manis, tomat, dan rempah-rempah.

\subsection{Kajian Pustaka}

Menurut Gislen (2008), Salad dressing adalah cairan agak kental yang digunakan untuk memberikan rasa pada sayuran segar atau buah-buahan, fungsi dressing pada salad sama halnya fungsi sauce pada makanan yaitu memperkaya rasa dan aroma. Pada dasarnya dressing dapat dibedakan menjadi oil and Vinegar dressing dan emulsified dressing yaitu mencampur beberapa bahan hingga menyatu menjadi satu dressing (Swanson 2015). Jenis-jenis dressing yang favorit dari kategori oil - viegar dan emulsified dressing antara lain italian dressing, classic vinaigrette, green godess dressing, french dressing, ranch dressing, blue cheese dressing hingga thousand island dressing.

\subsection{Metode Penelitian}

Dalam penelitian ini merupakan penelitian pengembangan yaitu sebuah metode penelitian dengan melakukan serangkaian proses atau langkah-langkah untuk mengembangkan suatu produk baru atau menyempurnakan produk yang telah ada dengan melakukan pengendalian terhadap variable di luar objek yang dieksperimenkan, Best dan Kahn (2010).

Variabel penelitian adalah segala suatu yang ditetapkan oleh peneliti untuk dipelajari sehingga diperoleh informasi tentang hal tersebut, kemudian ditarik kesimpulan, hal ini sesuai dengan yang di tulis oleh Sugiyono (2014). Dalam penelitian ini memakai 1 variabel yaitu variabel $\mathrm{X}$ adalah buah mangga. Populasi dari penelitian ini adalah dressing yang lazim untuk disajikan pada sajian salad buah atau sayur, sedangkan sampel yang dipilih adalah thousand island dressing untuk 
dikembangkan tanpa menggunakan mayonaise digantikan dengan buah mangga.

Menurut Sugiono, One Shot Case Study adalah merupakan desain penelitian yang terdiri dari sebuah kelompok yang diberi perlakuan yang kemudian dilakukan observasi terhadap fenomena hasil yang terjadi. Dalam penelitian ini dilakukan uji organoleptik yaitu uji sensori dengan mekanisme uji hedonik dan uji mutu hedonik yang dilakukan oleh 25 orang panelis terlatih dibidang kuliner. Para panelis diminta untuk mencoba dressing yang sudah dibuat kemudian memberikan nilai pada tabel penilaian yang diberikan.

Menurut Valliant \& Richard (2010) mengatakan bahwa penentuan populasi dan sampel penelitian menjadi hal yang krusial karena hasil penelitian akan disimpulkan secara menyeluruh. Ketepatan dan keakuratan dalam penentuan populasi dan sampel penelitian akan memengaruhi kualitas hasil penelitian.

Sekaran \& Bougie (2016) menyatakan bahwa sampling process merupakan proses pemilihan jumlah yang tepat dari unsur-unsur yang tepat dari populasi, sehingga studi tentang sampel dan pemahaman tentang sifat atau karakteristiknya memungkinkan untuk mengeneralisasikan sifat atau karakteristik tersebut.

Jenis emulsified dressing pada umumnya menggunakan bahan dasar dairy product yaitu penggunaan telor. Dressing dengan kandungan dairy product menyebabkan banyak individu yang tidak bisa mengonsumsi dressing tersebut karena alasan tertentu. Oleh sebab itu, dilakukan penelitian dan pengembangan salah satu jenis emulsified dressing yaitu thousand island dressing, dibuat tanpa menggunakan bahan yang mengandung dairy product dengan menggunakan bahan utama buah mangga.

\subsubsection{Teknik Pengumpulan Data}

Sekaran \& Bougie juga mengatakan bahwa data primer adalah kumpulan data yang didapatkan dari sumber asli yang sesuai dengan tujuan penelitiannya. Penelitian ini menggunakan data primer dari hasil kuisioner tentang Penggunaan buah mangga dalam pembuatan thousand island dressing sebagai pengganti penggunaan mayonnaise dengan empat aspek yaitu aspek rasa, warna, tekstur dan aroma. Panelis dapat menilai setiap aspek bantuan skala dan memberi tanggapan pribadinya pada kolom yang sudah disediakan.

Menurut Stone, Bleibaum, dan Thomas (2013), uji organoleptik atau uji sensori adalah sebuah penelitian yang dilakukan untuk menganalisa aspek rasa, warna, testur dan aroma terhadap pengujian sebuah produk yang didasarkan pada proses penginderaan. Maka dari itu pengujian organoleptik mempunyai peranan penting dalam penerapan kualitas suatu produk. Penelitian dan pengembangan dilakukan dengan penyebaran uji sensorik hedonik dan mutu hedonik pada inovasi dressing menggunakan buah mangga sebagai pengganti mayonnaise. Uji Hedonik dikutip di dalam buku karangan Setyaningsih, Dwi, Apriyantono \& Sari (2014) Uji hedonik atau kesukaan adalah untuk mengetahui respon panelis terhadap sifat mutu yang umum. Uji hedonik memberikan pernyataan kesan tentang baik atau buruknya suatu produk. Uji ini dilakukan untuk mengetahui tingkat kesukaan produk yang satu dengan produk yang lain secara langsung. Uji ini dapat diaplikasikan saat pengembangan produk atau pembanding produk.

Menurut Sarastani (2014). Uji hedonik dilakukan dengan cara panelis diminta tanggapan pribadinya tentang kesukaan atau ketidaksukaannya terhadap komoditi yang dinilai, bahkan tanggapan dengan tingkatan kesukaan atau tingkatan ketidak sukaannya dalam bentuk skala hedonik. Sedangkan untuk Uji mutu hedonik merupakan kesan mutu hedonik lebih spesifik, yaitu tidak sekedar suka atau tidak suka tetapi bersifat kesan spesifik dari sifat khas produknya. Maka dari itu dilakukan uji mutu hedonik untuk mengetahui kualitas produk penggunaan mangga sebagai bahan thousand island dressing yang telah di teliti.

Tabel 2 Skala Hedonik dengan 5 Skala Numerik

\begin{tabular}{|l|c|}
\hline \multicolumn{1}{|c|}{ Skala Hedonik } & Skala Numerik \\
\hline Sangat Suka & 5 \\
\hline Suka & 4 \\
\hline Agak Suka & 3 \\
\hline Agak Tidak Suka & 2 \\
\hline Tidak Suka & 1 \\
\hline
\end{tabular}

Sumber : Saludung (2018)

Dengan skala tabel di atas maka dapat membantu untuk mengetahui tingkat kesukaan responden terhadap penggunaan mangga sebagai bahan pembuatan thousand island dressing. Skala hedonik dapat digunakan sesuai kebutuhan dari peneliti dimulai dari sangat suka, suka, agak suka, agak tidak suka, tidak suka. Dengan adanya skala ini secara tidak langsung dapat mengetahui perbedaan antar variable. Kesukaan seseorang terhadap penggunaan mangga sebagai bahan thousand island dressing penting dalam penelitian ini karena hal tersebut dapat memberikan penilaian dan penentuan dalam hasil penelitian. 
Tabel 3. Skala Mutu Hedonik dengan 5 Skala Numerik

\begin{tabular}{|l|c|}
\hline Skala Mutu Hedonik & Skala Numerik \\
\hline Sangat Baik & 5 \\
\hline Baik & 4 \\
\hline Agak Baik & 3 \\
\hline Agak Tidak Baik & 2 \\
\hline Tidak Baik & 1 \\
\hline
\end{tabular}

Sumber : Saludung (2018)

\subsubsection{Teknik Analisis Data}

Dalam penelitian ekspermen ini, teknik analisis data dilakukan dengan cara menggunakan analisis sensori yaitu mengidentifikasi dan mendiskripsikan aspek rasa, warna, aroma dan tekstur dari buah mangga sebagai bahan substitusi bahan mengandung dairy products sedangakan ratarata hitung dalam pengolahan data dari uji hedonik dan mutu hedonik dengan cara sebagai berikut: Total nilai per indikator di jumlahkan : total panelis sehingga peneliti akan mendapatkan hasil nilai rata-rata per aspek seperti rasa, warna, aroma, tekstur serta rata-rata secara keseluruhan terhadap penggunaan buah mangga pada thousand island dressing.

Perode penelitian ini berlangsung mulai dari Agustus - Desember 2018. Sedangkan pengambilan data uji sensori hedonik dan mutu hedonik dilakukan pada pada minggu ke dua di bulan oktaber 2018. Kedalaman ekperimen pada penelitian ini sebatas untuk mengetahui bagaimana jenis buah yang telah dipilih yaitu buah mangga dapat menggantikan rasa, aroma, warna, dan tekstur dari kandungan dairy product dalam pembuatan inovasi thousand island dressing.

\subsection{Hasil Dan Pembahasan Penelitian}

Dibawah ini merupakan tabel olahan data dari hasil uji coba panelis dengan teknik uji hedonik dan mutu hedonik pada thousand island dressing menggunakan mangga dan rempah-rempah.

Tabel 4

Uji Hedonik Thousand Island dressing

Menggunakan Bahan Dasar Mangga

\begin{tabular}{|c|c|c|c|c|c|c|c|}
\hline \multicolumn{8}{|c|}{ Inovasi Thousand Island dressing menggunakan buah mangga } \\
\hline \multicolumn{4}{|c|}{ Rasa } & \multicolumn{4}{|c|}{ Aroma } \\
\hline $\begin{array}{l}\text { Skala } \\
\text { Numerik }\end{array}$ & Total & Mean & $\begin{array}{l}\text { \% of } \\
\text { Total N }\end{array}$ & $\begin{array}{c}\text { Skala } \\
\text { Numerik }\end{array}$ & Total & Mean & $\begin{array}{l}\text { \% of } \\
\text { Total N }\end{array}$ \\
\hline 1 & 0 & \multirow{5}{*}{4,28} & $0 \%$ & 1 & 0 & \multirow{5}{*}{4,40} & $0 \%$ \\
\hline 2 & 0 & & $0 \%$ & 2 & 0 & & $0 \%$ \\
\hline 3 & 2 & & $8 \%$ & 3 & 1 & & $4 \%$ \\
\hline 4 & 14 & & $56 \%$ & 4 & 13 & & $52 \%$ \\
\hline 5 & 9 & & $36 \%$ & 5 & 11 & & $44 \%$ \\
\hline Valid & 25 & & $100 \%$ & Valid & 25 & & $100 \%$ \\
\hline
\end{tabular}

Sumber Olahan Data

Berdasarkan data diatas, dapat dideskripsikan bahwa aspek rasa dari sampel dressing berbahan dasar buah mangga, dapat diterima melalui uji sensori dengan tingkat kesukaan pada numerik 4 yaitu suka sebesar $56 \%$ dan rasa dressing dengan tingkat kesukaan sangat suka yaitu skal 5 sebanyak $36 \%$ dan sisanya adalah $8 \%$ dengan tingkatan agak suka.

Dari pemaparan tersebut dapat dikatakan bahwa aspek rasa dari Penggunaan mangga sebagai bahan thousand island dressing yang menggunakan buah mangga sebagai pengganti mayonnaise dapat diterima dengan baik karena menyerupai rasa dressing yang diinovasikan. Sedangkan untuk aroma dari thousand island dressing sebanyak 52\% dari responden menyatakan suka, 44\% memberikan penilaian sangat suka dan sebesar $4 \%$ agak suka.

Tingkat kesukaan yang tinggi pada aroma dressing berbahan dasar buah mangga dapat diartikan bahwa aroma dari dressing tersebut adalah dapat diterima dengan baik karena menyerupai dengan aroma dari dressing yang sebenarnya.

$$
\text { Tabel } 5
$$

Uji Hedonik Thousand Island dressing

Menggunakan Bahan Dasar Mangga

\begin{tabular}{|c|c|c|c|c|c|c|c|}
\hline \multicolumn{8}{|c|}{ Inovasi Thousand Island dressing menggunakan buah mangga } \\
\hline \multicolumn{4}{|c|}{ Wama } & \multicolumn{4}{|c|}{ Tekstur } \\
\hline $\begin{array}{c}\text { Skala } \\
\text { Numerik }\end{array}$ & Total & Mean & $\begin{array}{l}\text { \% of } \\
\text { Total N }\end{array}$ & $\begin{array}{c}\text { Skala } \\
\text { Numerik }\end{array}$ & Total & Mean & $\begin{array}{l}\text { \% of } \\
\text { Total N }\end{array}$ \\
\hline 1 & 0 & \multirow{5}{*}{4,25} & $0 \%$ & 1 & 0 & \multirow{5}{*}{4,50} & $0 \%$ \\
\hline 2 & 0 & & $0 \%$ & 2 & 0 & & $0 \%$ \\
\hline 3 & 1 & & $4 \%$ & 3 & 1 & & $4 \%$ \\
\hline 4 & 17 & & $68 \%$ & 4 & 9 & & $36 \%$ \\
\hline 5 & 7 & & $28 \%$ & 5 & 15 & & $60 \%$ \\
\hline Valid & 25 & & $100 \%$ & Valid & 25 & & $100 \%$ \\
\hline
\end{tabular}

Sumber Olahan Data

Berdasarkan data diatas, dari aspek warna inovasi thousand island dressing menggunakan bahan dasar buah mangga ini mendapatkan penilaian sebesar $28 \%$ sangat suka dengan warnanya, dan $68 \%$ suka dengan warna dressing tersebut.

Dapat diartikan aspek warna sangat bisa diterima dengan rata-rata tingkat kesukaan 4,25 hal ini dikarenakan warna merah bata dari buah mangga menyerupai warna dari thousand island dressing yang sebenarnya.

Pada aspek tekstur dari dressing berbahan dasar buah mangga ini juga mendapatkan respon bagus dari panelis dengan $60 \%$ sangat suka dan $36 \%$ suka dengan tekstur dari dressing tersebut. Artinya tekstur inovasi dressing ini menyerupai tekstur dari thousand island dressing. 
Tabel 6

Uji Mutu Hedonik Thousand Island dressing

Menggunakan Bahan Dasar Mangga

\begin{tabular}{|c|c|c|c|c|c|c|c|}
\hline \multicolumn{8}{|c|}{ Penggunaan mangga sebagai bahan thousand island dressing } \\
\hline \multicolumn{4}{|c|}{ Rasa } & \multicolumn{4}{|c|}{ Aroma } \\
\hline $\begin{array}{c}\text { Skala } \\
\text { Numerik }\end{array}$ & Total & Mean & $\begin{array}{l}\text { \% of } \\
\text { Total N }\end{array}$ & \begin{tabular}{|c|} 
Skala \\
Numerik
\end{tabular} & Total & Mean & $\begin{array}{l}\text { \% of } \\
\text { Total N }\end{array}$ \\
\hline 1 & 0 & \multirow{5}{*}{4,20} & $0 \%$ & 1 & 0 & \multirow{5}{*}{4,40} & $0 \%$ \\
\hline 2 & 0 & & $0 \%$ & 2 & 0 & & $0 \%$ \\
\hline 3 & 2 & & $8 \%$ & 3 & 1 & & $4 \%$ \\
\hline 4 & 16 & & $64 \%$ & 4 & 13 & & $52 \%$ \\
\hline 5 & 7 & & $28 \%$ & 5 & 11 & & $44 \%$ \\
\hline Valid & 25 & & $100 \%$ & Valid & 25 & & $100 \%$ \\
\hline
\end{tabular}

Sumber Olahan Data

Tabel diatas menjelaskan bahwa rasa dari inovasi dressing berbahan mangga mempunyai mutu yang baik dengan pencapaian $64 \%$, penilaian sangat baik sebesar $28 \%$ dan agak baik sebesar $8 \%$. Secara rata-rata kualitas atau mutu dari rasa dressing berbahan buah mangga ini adalah 4,20 yang artinya bermutu bagus. Sedangkan mutu dari aroma dressing berbahan buah mangga ini adalah $52 \%$ menyatakan bermutu baik, 44\% menyatakan bermutu sangat baik dan $4 \%$ menyatakan mutu agak baik. Dengan pencapaian mean 4,40 dapat diartikan bahwa rasa inovasi dressing dengan bahan utama buah mangga harum manis ini sangat mirip dengan dressing yang sebenarnya dan memiliki aroma thousand island meskipun terbuat dari buah mangga sebagai pengganti mayonnaise.

\section{Tabel 7}

Uji Mutu Hedonik Thousand Island dressing

Menggunakan Bahan Dasar Mangga dan Tomat

\begin{tabular}{|c|c|c|c|c|c|c|c|}
\hline \multicolumn{8}{|c|}{ Penggunaan mangga sebagai bahan thousand island dressing } \\
\hline \multicolumn{4}{|c|}{ Wama } & \multicolumn{4}{|c|}{ Tekstur } \\
\hline $\begin{array}{l}\text { Skala } \\
\text { Numerik }\end{array}$ & Total & Mean & $\begin{array}{l}\text { \% of } \\
\text { Total N }\end{array}$ & $\begin{array}{c}\text { Skala } \\
\text { Numerik }\end{array}$ & Total & Mean & $\begin{array}{l}\% \text { of } \\
\text { Total N }\end{array}$ \\
\hline 1 & 0 & \multirow{5}{*}{4,36} & $0 \%$ & 1 & 0 & \multirow{5}{*}{4,48} & $0 \%$ \\
\hline 2 & 0 & & $0 \%$ & 2 & 0 & & $0 \%$ \\
\hline 3 & 1 & & $4 \%$ & 3 & 2 & & $8 \%$ \\
\hline 4 & 14 & & $56 \%$ & 4 & 9 & & $36 \%$ \\
\hline 5 & 10 & & $40 \%$ & 5 & 14 & & $56 \%$ \\
\hline Valid & 25 & & $100 \%$ & Valid & 25 & & $100 \%$ \\
\hline
\end{tabular}

Sumber Olahan Data

Berdasarkan data diatas, dapat dikatakan bahwa warna dressing berbahan buah mangga mempunyai kualitas atau mutu warna yang baik dengan pencapaian mean 4,36 yang artinya kemiripan warna yang tinggi dengan dressing yang sebenarnya. Selain itu untuk tekstur dari dressing tersebut mempunyai mutu yang bagus dengan kekentalan dan tekstur yang sesuai dengan dressing thousand island sehingga secara data mencapai mean 4,48 dengan rincian $56 \%$ penilaian dengan skala 5 yang berarti sangat bermutu dan $36 \%$ slala 4 yang artinya bermutu. Dari paparan tersebut dapat dikatakan bahwa warna inovasi dressing ini mempunyai kemiripan yang tinggi dengan dressing sebenarnya dan memiliki tektur dengan tingkat kekentalan dressing berbahan buah mangga yang berkualitas bagus.

\subsection{Kesimpulan}

Penelitian dan pengembangan ini bertujuan untuk menginovasikan thousand island dressing yang merupakan jenis emulsified dressing dan banyak digemari masyarakat, tanpa menggunakan mayonnaise dan untuk menghasilkan tingkat kekentalan yang sesuai dengan tektur yang sebenarnya digunakan buah mangga harum manis.

Pemilihan buah mangga harum manis sebagai bahan utama karena jenis buah mangga harum manis memiliki karakteristik tekstur yang kental apabila dihaluskan, memiliki rasa yang mirip dengan thousand island dressing apabila sudah dicampur dengan buah tomat dan rempah-rempah dan mempunyai kandungan nutrisi yang memadai untuk kebutuhan tubuh manusia.

Dari hasil uji organoleptik yang dilaksanakan oleh para panelis terlatih dengan melakukan uji hedonik dan mutu hedonik didapatkan hasil bahwa penggunaan mangga harum manis sebagai bahan pengganti mayonnaise dalam pembuatan thousand island dressing dari aspek rasa, aroma, warna dan tekstur yang dapat diterima dan disukai oleh para panelis sehingga inovasi atau pengembangan thousand island dressing menghasilkan dressing yang bermutu atau berkualitas baik.

Dapat dikatakan bahwa hasil penelitian dan pengembangan terhadap thousand island dressing dengan menggunakan bahan utama buah mangga menghasilkan dressing yang sangat layak untuk dikonsumsi karena menghasilkan rasa dengan tingkat kemiripan yang tinggi, warna dengan tingkat kemiripan yang tinggi, tektur dengan tingkat kemiripan yang tinggi dan tektur dengan tingkat kemiripan yang tinggi dengan thousand island dressing yang sebenarnya, sehingga bisa dijadikan sebagai alternatif dressing bagi masyarakat penggemar thousand island dressing yang tidak bisa mengonsumsi dairy produk karena alasan tertentu. Saya mengucapkan banyak terima kasih kepada LPPM UPH yang telah memfasilitasi pelaksanaan penelitian ini dan tentunya semua pihak yang telah membantu dalam proses penulisan artikel ini, kiranya artikel ini bisa berguna bagi yang membacanya. 


\section{Daftar Pustaka}

[1] Almatsier, Sunita. 2009. Prinsip Dasar IImu Gizi. PT Gramedia Pustaka Utama. Jakarta

[2] Best, J. W. \& Kahn, J. V. 2010. Research in education, $\left(5^{\text {th }}\right.$ ed.). New Delhi: PrenticeHall of India Pvt. Ltd.

[3] Gisslen, W. 2008. Professional cooking $\left(8^{\text {th }}\right.$ ed.). United Kingdom: Wiley.

[4] Saludung, J. 2018. Pengembangan dan penerapan model berbagai jenis makanan kue berbasis lokal dan ecopreneurship. Makassar.

[5] Sarastani, D. 2012. Penuntun praktikum analisis organoleptik. Bogor: Program Diploma Institut Pertanian Bogor.

[6] Sekaran, Umar \& Bougie, Roger. (2016). Research Methods for Business A Skill Building Approach ( $7^{\text {th }}$ ed.). United Kingdom: John Wiley \& Sons Ltd.
[7] Setyaningsih, Dwi, Apriyantono, A., \& Sari, M. P. 2010. Analisis sensori untuk industri pangan \& argo. Bogor: IPB Press.

[8] Stone, Bleibaum, \& Thomas 2012. Sensory evaluation practices: Food science and technology, (4 ${ }^{\text {th }}$ Ed.). London: Academic Press. Cemerlang Publishing.

[9] Sugiyono. (2014). Metode Penelitian Pendidikan Pendekatan Kuantitatif, Kualitatif, dan $R \& D$. Bandung: Alfabeta.

[10] Swanson, Steven (2015). Vinaigrette: The Tools, Techniques, and Ingredients to Make Any Salad Dressing. United Kingdom: HarperCollins Publisher Ltd.

[11]USDA, United States of Agriculture, (2018). Mango Grading Manual. United States Department of Agriculture. USA.

[12] Valliant, J. \& Richard, B. 2010. Finite population sampling and inference: $A$ prediction Approach. London: Wiley. 